\title{
EFFECT OF ARCHITECTURAL DESIGN CHARACTERISTICS AFFECTING DESIGN SIMPLICITY ON AFFORDABILITY IMPROVEMENT OF CORE HOUSING SCHEMES
}

\section{Dr. Nnaemeka Bennet Christian Dillon Okoye ${ }^{1}$, Prof. Ikechukwu Onyegiri² and Dr. Marcellinus Okafor ${ }^{3}$}

Department of Architecture, School of Environmental Design and Technology, Federal Polytechnic Oko, Nigeria. E-mail: emii2him@gmail.com

Department of Architecture, Faculty of Environmental Sciences, Imo State University, Owerri, Nigeria. E-mail: onyegiriikechukwu@ gmail.com

Department of Architecture, Faculty of Environmental Sciences, Imo State University, Owerri, Nigeria. E-mail: arcdrmuokafor@gmail.com

Cite this article:

N.B.C.D. Okoye, I. Onyegiri, M. Okafor (2021), Effect of Architectural Design Characteristics Affecting Design Simplicity on Affordability Improvement of Core Housing Schemes. Journal of Advanced Research and Multidisciplinary Studies 1(1), 26-59. DOI: 10.52589/JARMS9P4A2M5S.

\section{Manuscript History \\ Received: 10 May 2021 \\ Accepted: 27 May 2021 \\ Published: 7 June 2021}

Copyright $(2020$ The Author(s). This is an Open Access article distributed under the terms of Creative Commons AttributionNonCommercial-NoDerivatives 4.0 International (CC BY-NC-ND 4.0), which permits anyone to share, use, reproduce and redistribute in any medium, provided the original author and source are credited.
ABSTRACT: Studies identify that architectural design characteristics affecting design simplicity enhance core housing affordability. Effect of this attribute for affordability improvement, crucial in establishing design strategies for affordable low-cost urban homes, is lacking. Study examined this effect in Anambra State of Nigeria, using mixed method approach (primary data sourced from personal interviews, and questionnaire on 242 sampled residents from a 540 population. Using Kruskal-Wallis test and Spearman's Rank-Order correlation for analysis, all prototypes were found nonaffordable, with p-value of 0.000 for significant variation for affordability. Significant relationship, strong and positive ( $p$ value, 0.000; correlation coefficient 0.778), was established between architectural design characteristics affecting design simplicity and affordability. Recommendations for improving core housing affordability include: minimal floor area for initial unit (studio apartments for households earning below N161, 000 monthly, 1-bedroom and 2-bedroom prototypes for those earning between N161, 000 and N200, 000); simple geometric plans; and local building materials for roof covering.

KEYWORDS: Architectural Design Characteristics, Design Simplicity, Core Housing Schemes, Public Housing, Housing Affordability 


\section{INTRODUCTION}

Housing issues have been discussed in several global summits; such as the 1996 Habitat summit at Istanbul, the 2000 New York, United Nations Millennium Development Goals (MDGS) summit, the 2002 World Summit in Johannesburg and the 2005 La Havana, UN Sustainable Cities Documentation of Experience Programme (Ugonabo \& Emoh, 2013). Still urban housing affordability issues (particularly concerning developing countries) have notably lingered in global housing debates, because of the socio-economic importance of the subject. The reality of a mismatch between affordable housing requirements and what is provided buttresses the urgent need to address this area. Such a mismatch is witnessed in Nigeria, a developing country of Africa where, according to World Bank (2018), demand for affordable housing is large and growing, in the face of a sizeable deficit of 17 million units. Moreso, majority of houses produced cater for the upper income households, leaving an acute housing shortage for middle and lower income households (World Bank, 2018). Anambra State of Nigeria, with $60 \%$ of its population as urban dwellers, is witnessing housing scarcity such that the provision of adequate and affordable housing for the low-income people is critical (Ugonabo \& Emoh, 2013).

Anambra State government's effort, principled on the conventional full-provision system of housing provision, has so far not benefitted the low-income people. The whole housetypes developed through this system usually come with increased cost of the habitable unit. Aduwo, Edewor, and Ibem (2016) opine that majority of the people earning low incomes lack the financial muscle to acquire/build completed houses. The need for the provision of some type of housing for them however lingers. The best option seems to be a type of habitable housing that can be partially provided and then incrementally developed by residents while in occupation. Such a concept is already known and is regarded as core housing or incremental housing.

According to Abrams (1964), core housing is a low-cost housing delivery strategy intended for households who cannot afford whole houses (full-provision/finished), due to their lean income disposition. Likewise, Maly and Tamyo (2010) explain core housing as a low-cost housing provision of minimal but habitable structures which households incrementally add on to while living there. Generally, this housing strategy encourages the initial provision of minimal, partial, but habitable housing units (core houses) which households in occupation leverage on for upgrading and expansion, as funds improve and needs arise. Napier (2002) reckons that countries such as Chile, Mexico, Brazil, Thailand, Turkey, Indonesia, ElSalvador, Kenya, Sudan, South Africa and Ghana, among others, have successfully used this strategy in housing delivery.

The use of core housing strategy for public housing provision, according to Ibem (2011) and Irouke, Ajah and Ivoke (2017) was first practiced in Nigeria in government aided self-help housing scheme, with the cooperation of the World Bank and governments in Nigeria in the 1970s. Enugu and Anambra State governments, among others, equally utilized this strategy in their public housing programmes (Ikekpeazu, 2018). Anambra State government in some cases-built core houses and allocated to people, while in others serviced lands were sold to the beneficiaries to develop using the government approved prototype designs. Although core houses are meant to be minimal in sizes and levels of finish and also to target households who cannot afford whole houses, preliminary observations made indicate that majority of the core houses developed appear far from being minimal and the benefitting households seem to 
be of wealthier class. Could it be that the core houses developed are not affordable for the targeted households, and they were displaced by households of higher incomes?

Pandelaki and Shiozaki (2010) aptly note that if crucial architectural design characteristics are not properly considered at the design stage, core house prototypes lacking in affordability may result. This could lead to the houses going for the higher income people who can afford them. Studies such as: Ike (1996), Napier (2002); Pandelaki \& Shiozaki, 2010; Maly \& Tamyo, 2012; Atamewan \& Olagunju (2017) have identified architectural design characteristics affecting design simplicity as promoting affordability improvement of core houses. However, empirical knowledge on the relationship between them, which is crucial in the formulation of design strategies for improved low-cost urban housing delivery is lacking. The lack of this information may have affected the design and production of affordable core houses. This scenario, having adverse effect on the urban low-income dwellers, applies to Anambra State. This study, addressing this gap with a view to establishing design strategies for affordable low-cost urban homes, investigated the effect of architectural design characteristics affecting design simplicity on affordability improvement of public core housing schemes in Anambra State, Nigeria.

To achieve this, the following objectives were pursued, and they were meant to:

i) examine affordability of core houses in the existing public core housing estates in Anambra State for intended residents; and

ii) ascertain the relationship between architectural design characteristics affecting design simplicity of public core houses in Anambra State and affordability.

The following research questions were pursued in order to realize the objectives, namely:

i. How affordable for intended residents are core houses in the existing public core housing estates in Anambra State?

ii. What is the relationship between architectural design characteristics affecting design simplicity of public core houses in Anambra State and affordability?

The hypotheses tested were:

Ho1: Affordability for intended residents of core houses in the existing public core housing estates in Anambra State do not significantly vary.

Ho2: Architectural design characteristics affecting design simplicity of public core house in Anambra State has no significant relationship to its affordability. 


\section{LITERATURE/THEORETICAL UNDERPINING}

\section{Core Housing}

A core house has been described by various studies: Abrams (1964); Napier (2002); Pandelaki and Shiozaki (2010); Goethert (2010); and Maly and Tamyo (2012) as a permanent structure professionally designed to be initially minimal in size and incomplete but habitable, with the potential to be upgraded incrementally, based on need and improvement of resources. The low-income disposition of households, the deficiencies of the full-provision house types in affordability, and the non-availability of mortgage financing in housing provision for them necessitated the originating of the core housing strategy (Greene \& Rojas, 2008). There appears to be a problem in defining the target group for core housing by simply using the income group stratification, because of the global ambiguity resulting from disparity in purchasing power. While it could be appropriate to design core housing only for the low-income in a particular location the inculcation of the middle-income group may also be found relevant in another scenario. The underlying basis is that globally, core housing is conceived to meet up with affordability for households who cannot afford the conventional whole houses because of their lean income status (Abrams, 1964; Napier, 2002; Greene \& Rojas, 2008; Pandelaki \& Shiozaki, 2010). Such households, irrespective of income group, therefore define the intended beneficiaries or residents for core housing schemes in a given locality, and should be identified and considered in the conception, implementation and evaluation of such schemes. Unfortunately, it appears this has scarcely been the case. It is this approach that is adopted in this study.

\section{Housing Affordability}

Housing affordability is seen as a measure of the extent to which housing price for a given standard of housing impinges upon a household's "income to live on", or their capacity to meet their total household need (Hancock, 1993 cited in Milligan, 2003). It is seen as a measure of the ratio between what households pay for their housing and what they earn and the cost of house against the amount buyers can afford (Sharipah \& Sidi, 2011). Housing financing is usually either through personal savings or mortgage financing (Mutisya, 2015). Majority of households earning low incomes have no access to mortgage loans (Breimer, 2011); what is relevant to them therefore is affordability relating to house acquisition through personal savings. "House price to income ratio" is reckoned as one the most common measures of affordability for houses acquired through personal savings (Gudeta, 2010; Breimer, 2011). The ratio is that the house price should not exceed $2^{1 / 2}$ (2.5) times of household's annual income or 30 times of the household's average monthly income (Grimmes, 1976; Feins and Lane, 1981 cited in Ndubueze, 2009) in expressing. A house acquired through personal savings is affordable therefore if house price (HP) $<$ or $=2.5 \mathrm{x}$ household's average annual income (HAAI) or $30 \mathrm{x}$ household's average monthly income (30 $\mathrm{x}$ HAMI or 30HAMI). Affordability measure can as such be viewed as the relationship between HP and 2.5 HAAI or 30HAMI. Households whose " $2 \frac{1}{2} 2$ times average annual income" are less than or equal to the price of the least of the whole house types in a place therefore constitute the intended beneficiaries of core housing. It implies that a core houses should be delivered at prices lower than the price of the least of the whole house types in order to justify it as an affordable alternative. 
A review of studies on affordability of core housing schemes: Pandelaki and Shiozaki (2010); Ibem (2011); Maly and Tamyo (2012); Ibem, Aduwo and Ayo-Vanghan (2015); Atamewan and Olagunju (2017), indicates their being affordable for the residents in majority of the cases. However, a good number of the residents were of the middle and high income groups (in Ibem, 2011; Ibem, Aduwo \& Ayo-Vanghan, 2015). Secondly, the houses were acquired mainly through mortgage loans (Pandelaki \& Shiozaki, 2010; Ibem, 2011; Maly \& Tamyo, 2012). In the situation where the houses were acquired without mortgages and the respondents were of low-income disposition such as the case in Atamewan and Olagunju (2017), majority of the respondents $(85.1 \%)$ were found indicating that their houses are not affordable. Despite their non-affordability, the study revealed that most respondents preferred this type of housing (core housing), which is on incremental basis. As such, there remains a gap in empirical studies on how to provide affordable low-cost homes through the core housing strategy for households, particularly where mortgage financing is lacking. It is therefore pertinent to seek for ways of improving on the affordability of this strategy such that it can benefit the low-income households better.

Studies: Abrams (1964), Ike (1996), Faculty of Engineering and Architecture, University of Khartoum, Sudan (FEAUKS, 2010), Pandelaki and Shiozaki (2010), Gattoni, Goethert and Chavez (2011), Breimer (2011), University of Minnesota Centre for Urban and Regional Affairs (UMCURA) (2015) and Atamewan and Olagunju (2017) have identified architectural design characteristics affecting design simplicity as an attribute promoting affordability of core housing schemes. In Atamewan and Olagunju (2017) studying incremental construction (core housing) for low-income housing delivery in Bayelsa State, Nigeria, the low-income people were found to build their houses according to their abilities starting with a room; because this simpler form of structure is more affordable. In Gattoni, Goethert and Chavez (2011) while reporting on the proceedings of a training session on incremental housing strategies for urban growth found that the poor would need just a basic shelter to start with. Equally in University of Minnesota Centre for Urban and Regional Affairs (UMCURA) (2015) studying the best practices to reduce the cost of affordable housing found that the reduction of the unit cost for new developments through simpler designs resulted in the reduction of per unit subsidy from funders. Ike (1996) and Breimer (2011) also in the study on affordable homes as a guide to easy home-building and open building as an approach for more effective core housing implementation respectively discovered that low-income families merely needed where to lay their heads (a lower standard house) suggesting a basic shelter. Abrams (1964) recommends the provision of 1-room core houses, instead of more elaborate ones, for poor families as a way to meet up with the affordability requirements. Pandelaki and Shiozaki (2010) studying core housing in Indonesia found that the concept has strength in its simple designs (reduction of house floor area and decreasing of building material specification). The study found that the affordability of the Rumah Sangat Sederhana (RSS) or Very Simple Free-Standing House (core house) was as a result of the prototype's simplicity. Atamewan and Olagunju (2017) found that the low-income people prefer to use simple and locally sourced traditional materials such as earth for construction because of their affordability. Ike (1996) found that the urban single-room tenement unit usually accommodates almost all family activities (sleeping, sitting, eating, cooking, working, storage, etc.) just in one room. The study considers it as a worthwhile exercise for the architect to attempt to accommodate all household activities for a poor family of six, for instance, in a space of about $4.8 \mathrm{~m}$ by $3.6 \mathrm{~m}$. 


\section{Architectural Design Characteristics Affecting Design Simplicity}

From studies, architectural design characteristics affecting design simplicity has been highlighted to consist of the following: (i) simplicity in size of initial floor area (Abrams, 1964; Ike, 1996; Pandelaki and Shiozaki, 2010; Gattoni, Goethert and Chavez, 2011; Breimer, 2011; VanEenoo, 2011; UMCURA, 2015; Atamewan and Olagunju, 2017); (ii) simplicity in shape of initial house (Bradley, 2011; Esenwein, 2016; Widewalls Editorial ,2017); (iii) simplicity in specification for wall material (Owoeye and Amole, 2012; Olotuah and Taiwo, 2013 and Ayoola and Amole, 2014; Pandelaki and Shiozaki, 2010; Atamewan and Olagunju, 2017) (iv) simplicity in specification for roof covering (Bradley, 2011, Esenwein, 2016) and (v) simplicity in specification for floor covering (Bradley, 2011, Esenwein, 2016). So far a lot has been said concerning architectural design characteristics affecting design simplicity of prototype core house and affordability. What remains is to investigate the relationship between them in order to know how this attribute affects affordability. Such knowledge would be useful in establishing design strategies for affordable low-cost urban homes.

\section{Theoretical Framework}

This study is based on the theoretical platform of Maslow's Theory on Hierarchy of Needs, which is considered relevant to this study because it explains the phenomenon being studied. The theory suggests that people are motivated by a desire to satisfy their basic needs first before strongly desiring the satisfaction of the secondary needs. Expressed by A.H. Maslow in his book "Motivation and Personality", the theory propounds that the most basic level of needs must first be met before the individual strongly desires, or focuses motivation upon, the secondary needs (Maslow, 1970). Maslow's clarification of hierarchy of needs consists of five levels of cognitive needs, according to the order of importance, namely: psychological needs, safety needs, belongingness and love needs, esteem needs, and self-actualization needs. Abraham Maslow's theory on hierarchy of needs considers certain human needs as more basic and critical than others (Zavei \& Jusan, 2010). According to the theory, the physiological needs are the most basic needs of man and should be first met before others in the order: safety, social belongingness, esteem and self-actualization needs. They consist of the physical requirements for human survival and will lead to body malfunction in one way or another if they are not met. They include breathing, water, food, sleep, clothing and shelter.

Among the psychological needs, shelter is the one that essentially has to do with housing and it connotes protection from something, such as weather elements intrusions. Greene and Rojas (2008) concurs that the primary function of a house from the household's point of view is to provide protection against the cold, rain, sun and wind, and that reaching this standard is the first priority after accessing land. Salami (2011) buttresses this in admitting that with shelter being placed at the base of Maslow's pyramid or triangle, provision of it has always been the basic function of buildings. The study recognized that if there is no affordable housing for the households, there will be no grounds to talk about other housing needs in Maslow's pyramid. 


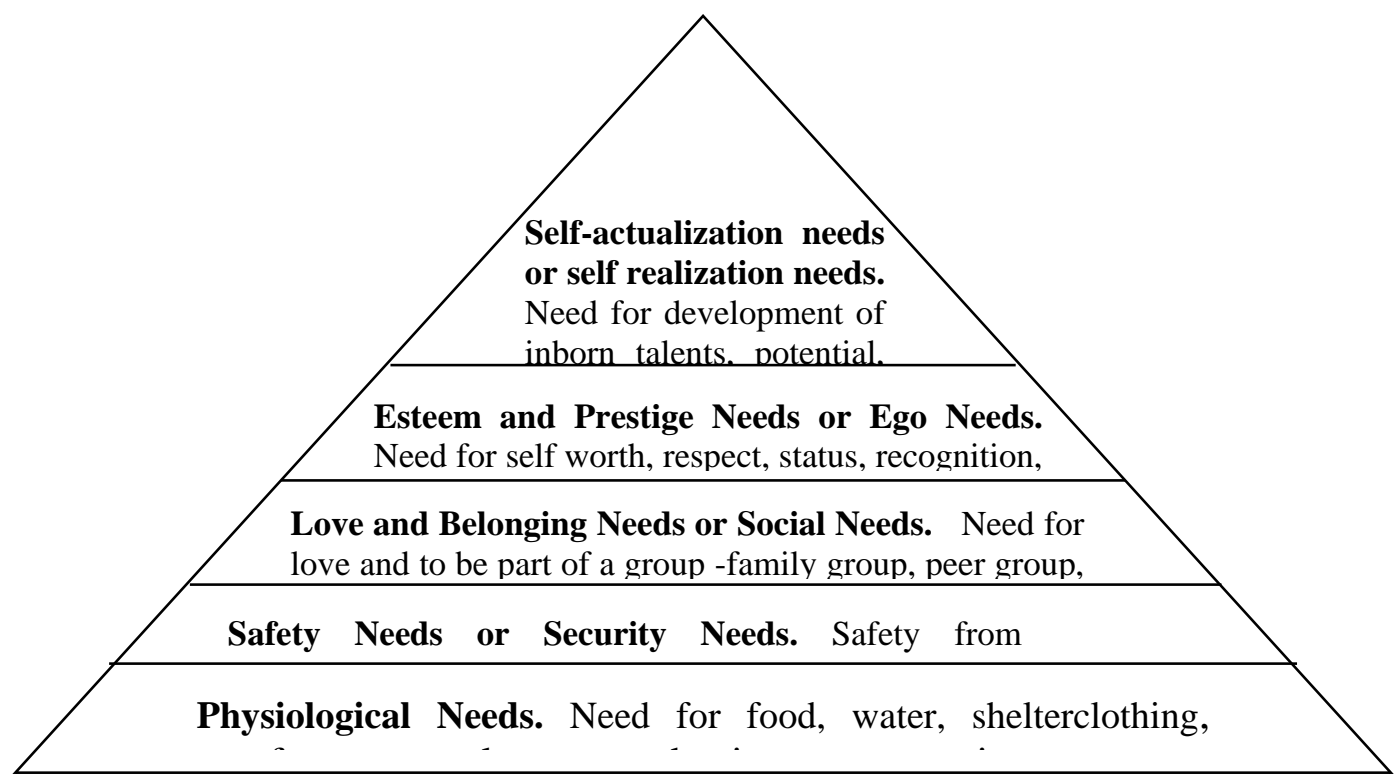

Figure 1: Abraham Maslow's Hierarchy of Needs Triangle

Source: Onah (2015)

From the above it can be deduced that the most basic need of housing users is provision of simple structures that serve the basic function of protection. It is when this has been achieved, according to Maslow's theory, that quest for other needs follow. Housing as a need therefore has to satisfy the aspect of the most basic needs before going on to the other areas. This expectation moreso becomes more relevant in the case of housing for the lowe-income households because of their lean economic disposition. It would be necessary to first address their most basic need in housing provision with whatever resources available before considerating other needs.

The theoretical underpinning for this study hinges on the connection between the provision of simple shelters for the basic function of protection, identified from Maslow's Hierarchy of Needs theory as the basic need of the housing users and the core housing principle of starting with a simple structure (core house) that meets the household's basic need of shelter, for affordability reasons, after which other needs can be met as expansion goes on. Therefore, Maslow's Hierarchy of Needs theory guides this study into focusing on how to produce designs that meet up with the affordability expectations of the intended residents of core housing strategy, based on their most basic needs (simple structure that provides shelter) and not the secondary ones, as majority of the existing prototypes seem to address.

The housing sector in Anambra State is fraught with the challenges of housing provision to its teeming urban population, particularly the low-income earners. This study utilizes Maslow's Hierarchy of Needs theory to point out what their most basic need in housing provision is. This is important so that it will form the basis for the design and implementation of core housing stratey for them, whereby the available resources are directed towards the 
most basic need, while opportunity to address the others avails through expansion, upgrading and modification. It endeavours to provide government with a necessary policy tool from the architectural design angle for improving affordability of core housing so that households earning low incomes could benefit from this strategy.

\section{METHODOLOGY}

This study covers the existing core housing estates proposed and built by the Federal and State governments under the public housing programme in Anambra State, Nigeria. The core housing estates that are still operational are located in Awka capital city. The study area for this study is therefore Awka capital city, which is the capital of Anambra State in Nigeria. Anambra State is one of the 36 states of the Nigerian Federation and one of the five states in the South-East Geo-political zone of the country (United Nations Human Settlements Programme, UN-HABITAT, 2009).

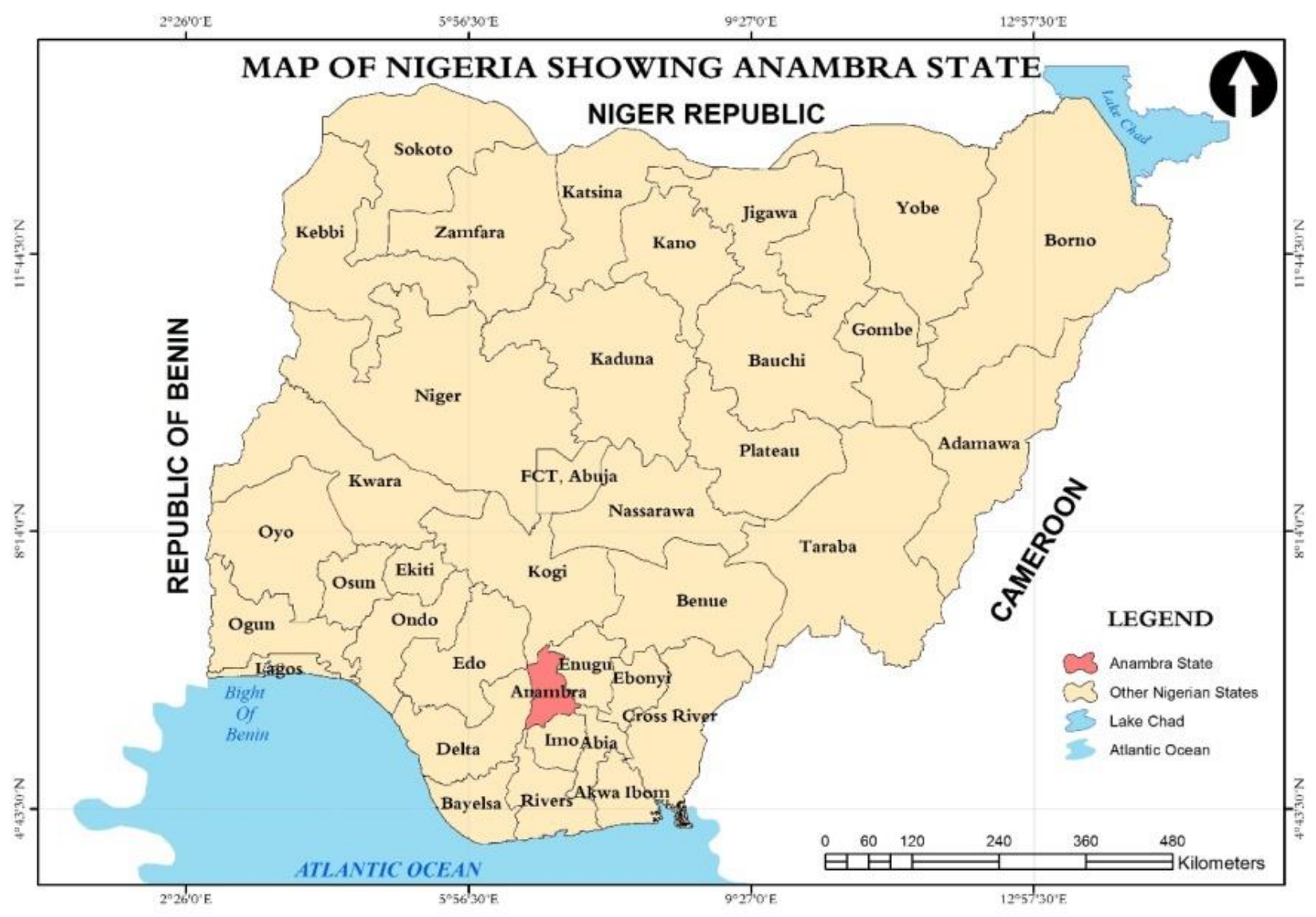

Figure 2: Map of Nigeria Showing Anambra State.

Source: Office of the Surveyor General of the Federation, Abuja 2012. 


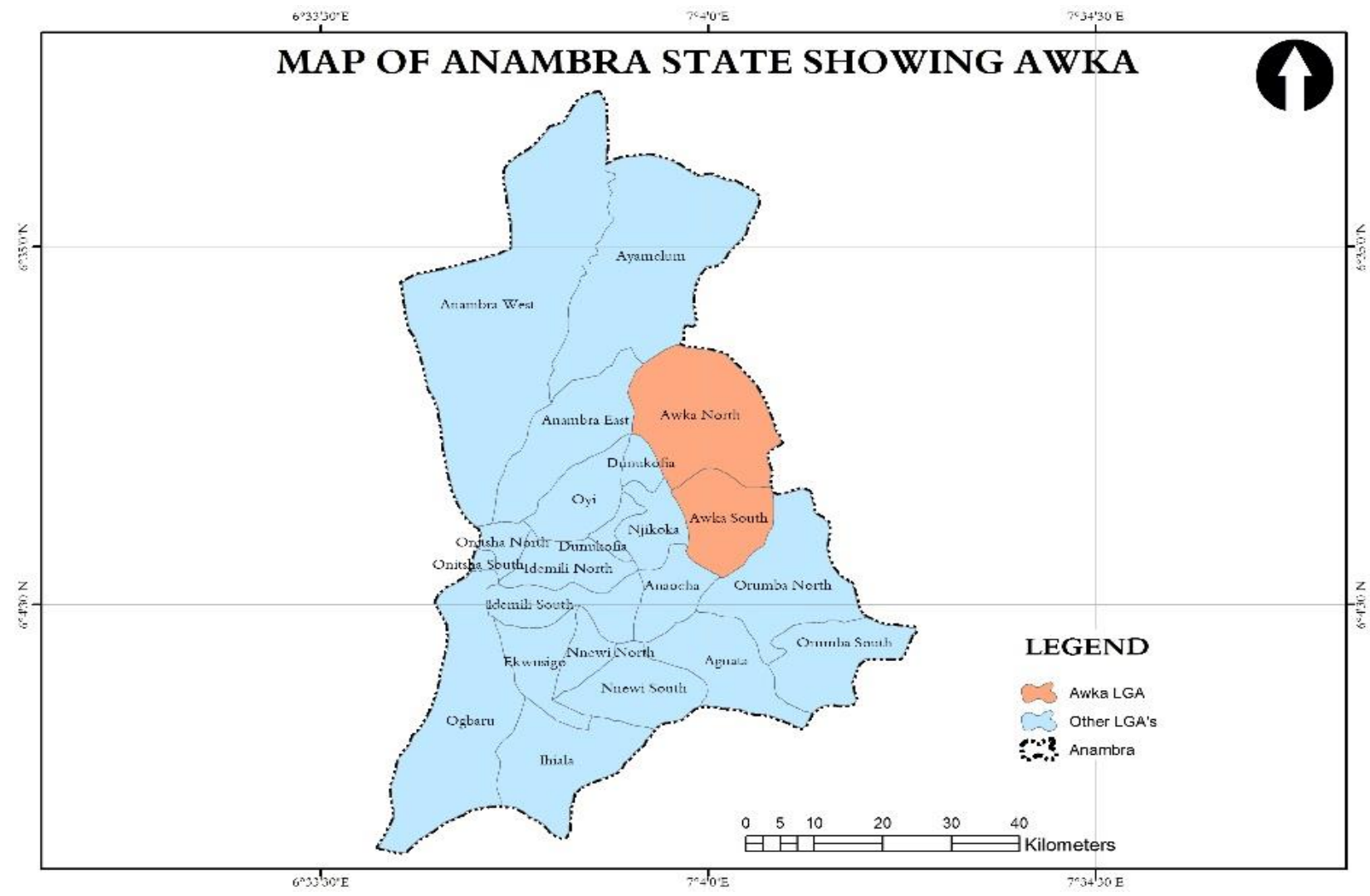

Figure 3: Map of Anambra State Showing Awka.

Source: Office of the Surveyor General of the Federation, Abuja 2012.

Awka capital city basically lies below 300 metres above sea level and forms a fairly level stretch with two ridges, both lying in a north - south direction, with the minor ridge rising at Ifite - Awka about 150 metres above sea level (UN-HABITAT, 2009). The plain surrounding this ridge hosts the area under consideration. A thick sequence of shale and sand stones which was formed in the Paleocene age underlie most of this area with a rich bed of sands and clay containing seams of lignite covering these strata (UN-HABITAT, 2009). Three notable soil types are identified, namely: loamy, clay and fine white sands, and laterite (which is poorly cemented, easily eroded and with moderate permeability). Awka capital city falls within the zone known as the rain forest zone of Nigeria, though the land have reduced the vegetation to a mixed savannah type due to consistent agricultural and economic activities. Rain forest trees such as Iroko, Orange, and Mango, Palm, Cola nut and Coconut trees could be found in the residential areas and along stream courses. Awka capital city has a record of high temperatures, about $27-28^{0} \mathrm{C}$ which increases to a peak of about $35^{\circ} \mathrm{C}$ between February and April which is the hottest period (UN-HABITAT, 2009). The coolest period on the other hand occurs from mid-July through December to early January which spans the middle of the rainy season to the harmattan period. The available warm temperature encourages outdoor activities. The area is characterized by periods of high humidity and rainfall. The figures for mean annual rainfall from $1979-1989$ is $1,485.2 \mathrm{~mm}$, with a mean monthly figure of $50 \mathrm{~mm}$. 
The study area is located within the tropical wet climate zone with clearly known wet season and dry seasons (UN-HABITAT, 2009). About eight of the twelve months of the year experience the rains while the remaining four are known to be dry. The two predominant winds in this area namely: the south-west monsoon wind and the north-east trade wind are responsible for these yearly seasons. The source of the south-east monsoon wind is the Atlantic ocean while the north-east trade wind originates from the Sahara desert. The peculiar harmattan period (a very dry and dusty time) takes place for about two weeks within the dry season sometime between the month of November and February.

According to the National Population Commision of Nigeria, NPC, (2006), the population of Awka capital city was estimated to be 113,660, comprising of Awka (86,593), Amawbia $(21,773)$ and Okpuno $(5,294)$. With an annual growth rate of $3.2 \%$ (NPC, 2006), the population at the year 2020 is projected to be 220, 094. The settlement pattern in the Awka capital city can be classified into two distinct parts namely: the built-up traditional setting and the sparsely developed/developing areas around it. The traditional setting is known to be overcrowded, generally unplanned, and with poor road systems. The areas around them are large open lands surrounding the few houses, found along Enugu-Onitsha expressway for example, which have been primarily used for agriculture. This settlement characteristic is crucial for planning matters in the capital city in order to maintain the peculiarities. In Awka town itself two major components are identifiable. The first is the older indigenous Igbo settlement with a palace and a market square at the centre, providing sufficient open spaces for recreation, religious, socio-cultural and economic activities. It also harbours a compact nature of individual family compounds which are walled and linked up with untarred roads and pathways. The second is the newly developing area grafted into the old settlement but separated by the Enugu-Onitsha expressway.

Mixed method research design was adopted for this study, because of the type of data required. The population of study was derived from residents of all existing public core housing estates (federal government and state government owned) developed in the public housing programme of Anambra State; represented by the household heads. A total number of 7 core housing estates, 1,173 housing units (all bungalows), and 1,430 dwelling units were developed in Anambra State (916 detached, and 257 semi-detached, having 2 dwelling units occupied by different households). From this number, the core houses built at Federal LowCost Housing Estate, Trans-Nkisi, Onitsha and AHOCOL Niger Close Housing Estate, G.R.A, Onitsha have been partially/totally demolished respectively. The remaining 5 estates developed by the Anambra State Home Ownership Company Limited (AHOCOL), Awka and the Anambra State Housing Development Corporation (ASHDC), Awka were therefore studied, comprising of 953 housing units and 1,210 dwelling units (257 were of the semidetached type with 2 dwelling units occupied by different households). To determine the maximum monthly income of households who cannot afford whole houses and therefore the intended residents for the core houses the affordability yardstick of not more than 2.5 times household annual income (Grimmes, 1976 and Feins and Lane, 1981 cited in Ndubueze, 2009) was applied because Anambra housing policy is based on outright house purchase without mortgage financing (see Personal interview protocol of the head of Estate Management department of ASHDC during pilot survey - Appendix A). A total of 6 Million Naira $(\$ 15,483.87)$ was established as price of the least of the whole houses developed in Anambra State as obtained from the personal interview protocol of the Head of Quantity Surveying department of ASHDC during the pilot survey (Appendix B). Imputing 6 Million 
Naira $(\$ 15,483.87)$ and $2.5 x$ Household Annual Income, the figure N200, 000 (\$516.13) was realized as the maximum monthly income of households who cannot afford whole houses and therefore the intended residents for the core houses. A classification for the intended residents according to income ranging from $\mathrm{N} 1,000$ (\$2.58) to $\mathrm{N} 200,000$ (\$516.13) was done grouping them thus: lower range $(\mathrm{N} 1,000$ - N80, 000 or $\$ 2.58$ - \$206.45), middle range $(\mathrm{N} 81,000-\mathrm{N} 120,000$ or $\$ 209.03$ - \$309.68) and upper range (N121, $000-\mathrm{N} 200,000$ or $\$ 312.26$ - \$516.13). Since the interest of the research is on the residents who fall into the group of those intended for the scheme, 540 households were isolated and noted from the 1,210 dwelling units as belonging to the group of intended residents for the core houses. Taro Yamane's formula was used to arrive at the sample size of 230 and an additional 5\% was added to take care of questionnaire that may not be properly filled or returned bringing the sample size to 242 . Through proportionate stratified random sampling procedure, the sample size of 242 was distributed according to the contribution each estate/prototype is making to the total population of 540 dwelling units as shown in Table 1.

Table 1: List of Existing Core Housing Estates in Anambra State for Study According to Prototypes/Dwelling Units

\begin{tabular}{|c|c|c|c|c|c|}
\hline $\mathbf{S} / \mathbf{N}$ & Name of Estate & $\begin{array}{c}1- \\
\text { bedroom }\end{array}$ & $\begin{array}{c}\text { 2- } \\
\text { bedroom }\end{array}$ & $\begin{array}{c}\text { 3- } \\
\text { bedroom }\end{array}$ & $\begin{array}{c}\text { Total } \\
\text { Dwelling } \\
\text { Units } \\
\end{array}$ \\
\hline 1. & $\begin{array}{l}\text { AHOCOL Think Home Estate } \\
\text { Phase 1, Agu-Awka, Awka } \\
\text { (PROTOTYPE AHOCOL 1) }\end{array}$ & & & 19 & 19 \\
\hline 2. & $\begin{array}{l}\text { AHOCOL Think Home Estate } \\
\text { Phase 2, Agu-Awka, Awka } \\
\text { (PROTOTYPE AHOCOL 2) }\end{array}$ & & & 43 & 43 \\
\hline 3. & $\begin{array}{l}\text { AHOCOL Oganiru Housing } \\
\text { Estate, Agu-Awka, Awka } \\
\text { (PROTOTYPE AHOCOL 3) }\end{array}$ & & & 27 & 29 \\
\hline 4. & $\begin{array}{l}\text { AHOCOL Inner City Layout, } \\
\text { Nkwelle, Awka (PROTOTYPE } \\
\text { AHOCOL 4) }\end{array}$ & & 3 & & 3 \\
\hline 5. & $\begin{array}{l}\text { ASHDC Ngozika Housing Phase } \\
1 \text {, Awka } \\
\text { (PROTOTYPES ASHDC 1, } 2 \text { and } \\
\text { 3) }\end{array}$ & 54 & 46 & 48 & 148 \\
\hline & Total & 54 & 49 & 139 & 242 \\
\hline
\end{tabular}

Source: Fieldwork (2016) 
The dependent variable for this study is "Affordability" while the independent variable is "Architectural design characteristics affecting design simplicity". From literature review affordability measure for a house acquired through personal savings is seen as the relationship between house price (HP) and 2.5 times Household average annual income (2.5HAAI) or $30 \mathrm{x}$ household average monthly income (30HAMI). The house is affordable if $\mathrm{HP}<$ or $=2.5 \mathrm{HAAI}$ or 30HAMI. The following data were established to measure affordability: (i) the mean of house price (MHP), and (ii) the mean of the households' average monthly incomes for $2 \frac{1}{2}$ years (2.5MHAAI) or 30 months (30MHAMI). The following variables were used to determine the mean of house price: (i) estate of residency variable 1; (ii) number of bedrooms in resident's house (house type) when it was first built variable 2; and (iii) lot and building prices of house types in the year 2017 - variable 3 . The mean of the households' average monthly incomes for $2 \frac{1}{2}$ years was determined from household's average monthly income - variable 4.

From literature review equally the following five variables were identified as constituting architectural design characteristics affecting design simplicity, namely: (i) simplicity in size of initial floor area; (ii) simplicity in shape of initial house; (iii) simplicity in specification for wall material; (iv) simplicity in specification for roof covering; and (v) simplicity in specification for floor covering. These variables were subjected to the opinion of head of the quantity surveying department of the Anambra Housing Development Corporation (ASHDC) and the researcher's experience, in order to identify the three that mostly contributed to decreasing building cost. The following were isolated, namely:

(ii) simplicity in shape of initial floor plan;

$$
\text { simplicity in specification for roof covering; }
$$

In ascertaining the relationship between architectural design characteristics affecting design simplicity of public core houses in Anambra State and affordability (Objective 2), an indirect approach was adopted in obtaining responses from the residents. Technical information was required from experts to know if the variables under investigation contribute to decreasing building cost. This is because, apart from having to do with the preference level of the respondents, the information sought also needed technical knowledge in order to confirm their influences on house price, hence affordability. Technical knowledge obtained from personal interview protocol of the head of department of Quantity Surveying (Appendix D) confirmed that the variables: (i) simplicity in size of initial floor area; (ii) simplicity in shape of initial floor plan and (iii) simplicity in specification for roof covering contribute in decreasing house price. The preference level of the respondents was then sought on these variables variables having confirmed their inpacts on house price.

Data collection, through questionnaire survey and personal interviews, was carried out between the months of February 2016 and October 2017. The questionnaire (Appendix E), which was structured on a 5-point Likert scale (ranging from Strongly disagree, 1, Disagree, 2, Neutral, 3, Agree, 4 and Strongly agree, 5) was tested for content validity, having Cronbach's Alpha value of 0.869 being above the acceptable value of 0.70 ; and for reliability by experts and it covered two aspects grouped under sections. Section A, based on Objective 
1, had three variables which were used in examining affordability of core houses in the existing public core housing estates in Anambra State for intended residents:

(i) variable 1 - estate of residency; and

(ii) variable 2 - number of bedrooms in resident's house (house type) when it was first built; and

(iii) variable 4 - household's average monthly income

Section B, based on Objective 2, had three variables which were used to generate data for architectural design characteristics affecting design simplicity in order to ascertain the relationship between this attribute and affordability:

(i) variable 5 - simplicity in size of initial floor area (SSF);

(ii) variable 6 - simplicity in geometrical shape of initial floor plan (SGS); and

(iii)variable 7 - Simplicity in specification for roof covering (SSR)

A total of $242(100 \%)$ copies of the questionnaire were distributed to heads of the households (or competent representatives) of the sampled dwelling units out of which 225 (93\%) were properly filled and returned. Personal interview protocols of the heads of departments of Town Planning (Appendix C) and Quantity Surveying (Appendix D) of ASHDC were conducted. The interview of the head of Town Planning department was to obtain information on dates of establishment/locations of each of the estates under study as whether within the city or outside the city at the establishment date, required in respect of objective 1 on affordability. The interview of the head of Quantity Surveying department was to elicit information on the lot/building prices of the various core house prototypes under study as at the Year 2017 (variable 3), required for objective 1 on affordability and the relationship between architectural design characteristics affecting design simplicity and affordability required for objective 2. Descriptive statistics was used for the presentation of data. Descriptive statistics and Kruskal-Wallis test were used for the analysis of data on objective 1, while Descriptive statistics and Spearman's Rank-Order correlation were applied for the analysis of data on objective 2 .

\section{RESULTS/FINDINGS}

\section{Results}

Objective 1: Affordability of core houses in the existing public core housing estates in Anambra State for intended residents

(i) The mean of house prices of the core houses under study were established, using: (a) the residents' estates of residency - variable 1 (Table 2); (b) number of rooms in residents' houses (house type) when they were first built - variable 2 (Table 3); and (c) lot and building prices of house types in the year 2017 - variable 3 (Table 4). 


\section{(a) Variable 1: Estate of residency}

Data on residents' estates of residency was required to determine the house prices of the various prototypes developed since they varied according to estates. The result as displayed in Table 2 shows $18(8 \%)$ of the respondents residing in AHOCOL THINK HOME 1 (AHOCOL 1), 40 (17.8\%) in THINK HOME 2 (AHOCOL 2), 26 (11.6\%) in AHOCOL OGANIRU (AHOCOL 3), 3 (1.3\%) in AHOCOL INNER CITY (AHOCOL 4) and 138 (61.3\%) residing in ASHDC NGOZIKA (ASHDC 1, 2 AND 3).

Table 2: Variable 1: Estate of Residency

\begin{tabular}{lcc}
\hline Response & Frequency $(\mathbf{N})$ & Percentage $(\boldsymbol{\%})$ \\
\hline AHOCOL THINK HOME 1 (AHOCOL 1) & 18 & 8 \\
AHOCOL THINK HOME 2 (AHOCOL 2) & 40 & 17.8 \\
AHOCOL OGANIRU (AHOCOL 3) & 26 & 11.6 \\
AHOCOL INNER CITY (AHOCOL 4) & 3 & 1.3 \\
ASHDC NGOZIKA (ASHDC 1, 2 AND 3) & 138 & 61.3 \\
Total & $\mathbf{2 2 5}$ & $\mathbf{1 0 0}$ \\
\hline
\end{tabular}

Source: Fieldwork (2017)

(b) Variable 2: Number of bedrooms in resident's house (house type) when it was first built.

The number of bedrooms in the residents' houses (house type) when they were first built (before expansion took place) was required given that the house prices varied according to house type. The result displayed in Table 3 shows that $51(22.7 \%)$ of the respondents resided in 1-bedroom apartments, $45(20 \%)$ in 2 bedroom apartments and the rest of $129(57.3 \%)$ of them lived in 3-bedroom apartments. This indicates that majority of them acquired 3 bedroom prototypes when the houses were first built.

Table 3: Variable 2: Number of Bedrooms in Resident's House (house type) when it was First Built.

\begin{tabular}{|c|c|c|}
\hline Response & Frequency & Percentage \\
\hline 1 Bedroom & 51 & 22.7 \\
\hline 2 Bedrooms & 45 & 20 \\
\hline 3 Bedrooms & 129 & 57.3 \\
\hline Total & 225 & 100 \\
\hline
\end{tabular}

Source: Fieldwork (2017) 


\section{(c) Variable 3 - Lot and building prices of house types in the year 2017}

Table 4 shows the house prices (lot and building prices) of the various prototypes in their locations (within the city). It also shows the house prices if the prototypes are located outside the city (city border). The 1 bedroom prototype developed at ASHDC Ngozika Housing Estate (NGOZIKA 1) with prices of 6.1 Million Nigerian Naira and 4.1 Million Nigerian Naira $(\$ 15,741.94$ and $\$ 10,580.65)$ respectively, within the city and outside the city respectively is the cheapest, followed by the 2 bedroom prototype at AHOCOL Inner City Layout (AHOCOL 4) with prices of 7.5 Million Nigerian Naira and 5.1 Million Nigerian Naira $(\$ 19,354.84$ and $\$ 13,161.29)$ respectively. Next is the 2 bedroom prototype built at ASHDC Ngozika Housing Estate (NGOZIKA 2) costing 7.7 Million Nigerian Naira and 5.3 Million Nigerian Naira (\$19,870.97 and \$13677.42) respectively, followed by the 3 bedroom prototype built at AHOCOL Think Home 1 and 2 (AHOCOL 1 and 2) costing 9.75 Million Nigerian Naira and 6.6 Million Nigerian Naira $(\$ 25,161.29$ and \$17,032.26) respectively. This is followed by the 3 bedroom prototype at ASHDC Ngozika Housing Estate (NGOZIKA 3) with prices of 9.9 Million Nigerian Naira and 6.75 Million Nigerian Naira (\$25,548.39 and $\$ 17,419.35$ ) within the city and outside the city respectively, and the costliest which is the 3 bedroom prototype developed at AHOCOL Oganiru Estate (AHOCOL 3) with prices of 10.5 Million Nigerian Naira and 6.9 Million Nigerian Naira (\$27,096.77 and \$17,806.45) within the city and outside the city respectfully.

Table 4: Variable 3 - Lot and Building Prices of House Types in the Year 2017

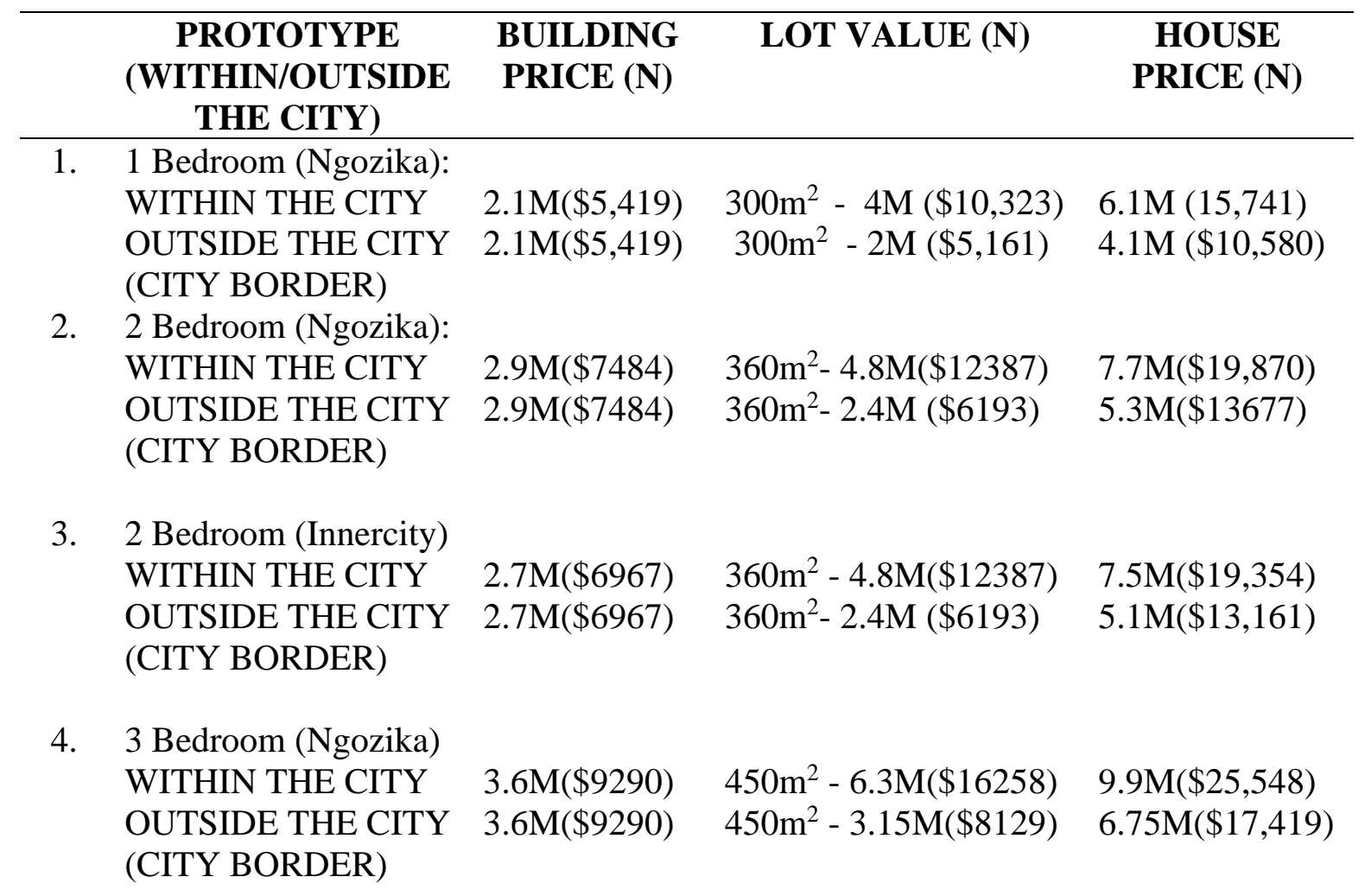




$$
\begin{array}{lllll}
\text { 5. } & 3 \text { Bedroom (Think } & & & \\
\text { Home } 1 \& 2) & 3.45 \mathrm{M}(\$ 8903) & 450 \mathrm{~m}^{2}-6.3 \mathrm{M}(\$ 16258) & 9.75 \mathrm{M}(\$ 25,161) \\
\text { WITHIN THE CITY } & 3.45 \mathrm{M}(\$ 8903) & 450 \mathrm{~m}^{2}-3.15 \mathrm{M}(\$ 8129) & 6.6 \mathrm{M}(\$ 17,032) \\
\begin{array}{l}
\text { OUTSIDE THE CITY } \\
\text { (CITY BORDER) }
\end{array} & & & \\
& & & \\
\text { 6. } & \begin{array}{l}
\text { 3 Bedroom (Oganiru) } \\
\text { WITHIN THE CITY }
\end{array} & 3.75 \mathrm{M}(\$ 9677) & 450 \mathrm{~m}^{2}-6.3 \mathrm{M}(\$ 16258) & 10.5 \mathrm{M}(\$ 27,097) \\
\begin{array}{l}
\text { OUTSIDE THE CITY } \\
\text { (CITY BORDER })
\end{array} & 3.75 \mathrm{M}(\$ 9677) & 450 \mathrm{~m}^{2}-3.15 \mathrm{M}(\$ 8129) & 6.9 \mathrm{M}(\$ 17,806) \\
\hline
\end{array}
$$

Source: Field work (2017). Compiled from Personal Interview Protocol with the Head of the Quantity Surveying Department, Anambra State Housing Development Corporation, Awka.

The mean house prices of the prototypes were then established from these variables. The result in Tables 5 shows the mean house prices within the city, where the prototypes under study were located at establishment time (Appendix C). The result indicates N6,100,000 $(\$ 15,742)-22.7 \%$, N7,500,000 (\$19,350) - 1.3\%, N7,700,000 (\$19,871) - 18.7\%, $\mathrm{N} 9,750,000(\$ 25,161)-25.8 \%, \mathrm{~N} 9,900,000(\$ 25,548)-11.6 \%$, and N10,500,000 (\$27097) $11.6 \%$, respectively as mean house prices in the city. It equally shows the mean house prices if the prototypes are located outside the city (city border). The result indicates N4,100,000 $(\$ 10,581)-22.7 \%, \mathrm{~N} 5,100,000(\$ 13,161-1.3 \%, \mathrm{~N} 5,300,000(\$ 13,677-18.7 \%, \mathrm{~N} 6,600,000$ $(\$ 17,0322$ - 5.8\%, N6,750,000 (\$17,419 - 20.0\%, and N6,900,000 (\$17,806 - $11.6 \%$, respectively as mean house prices outside the city (city border).

\section{Table 5: Mean House Prices}

\begin{tabular}{lccc}
\hline MHP within the city & MHP outside the city & Frequency & Percentage \\
\hline N6100000 $(\$ 15,742)$ & N4100000 $(\$ 10,581)$ & 51 & 22.7 \\
N7500000 $(\$ 19,350)$ & N5100000 $(\$ 13,161)$ & 3 & 1.3 \\
N7700000 (\$19,871) & N5300000 $(\$ 13,677)$ & 42 & 18.7 \\
N9750000 (\$25,161) & N6600000 $(\$ 17,0322)$ & 58 & 25.8 \\
N9900000 (\$25,548) & N6750000 (\$17,419) & 45 & 20.0 \\
N10500000 (\$27097) & N6900000 $(\$ 17,806)$ & 26 & 11.6 \\
Total & & $\mathbf{2 2 5}$ & $\mathbf{1 0 0}$ \\
\hline
\end{tabular}

Source: Fieldwork (2017)

(ii) The mean of the households' average monthly incomes for $2^{1} / 2$ years $(2.5 \mathrm{MHAAI})$ or 30 months (30MHAMI) was established based on the responses of the residents on their household's average monthly income as shown in Table 6. The result shows that $193(85.8 \%)$ of the respondents are within the N161, 000 - 200,000 or $\$ 415.48$ - $\$ 516.13$ range of income, $18(8 \%)$ within the $\mathrm{N} 121,000-160,000$ or $\$ 312.26$ - $\$ 415.48$ range, 8 (3.6\%) within N81, 000 - 120,000 or $\$ 209.03$ - $\$ 312.26$ range while only $6(2.7 \%)$ are within the N41, $000-$ N80, 000 or $\$ 105.81$ - $\$ 206.45$ range. This reveals that majority of the core housing 
households studied (94\%) are of the upper range (N121, $000-\mathrm{N} 200,000$ or $\$ 312.26-$ $\$ 515.13$ ) of the group of intended residents, only $3.6 \%$ of the middle range (N81, $000-$ $\mathrm{N} 120,000$ or $\$ 209.03-\$ 309.68)$, and a meagre $2.7 \%$ of the lower range (N1, 000 - N80, 000 or $\$ 2.58$ - \$206.45). This could imply that the lower and middle range households were not able to afford the houses and only a meagre percentage of them (6\%) did so, probably through some means other than that used in measuring affordability - savings from household income).

Table 6: Variable 4 - Household's Average Monthly Income

\begin{tabular}{lcc}
\hline Response & Frequency & Percentage \\
\hline N1,000-N40,000 $(\$ 2.58-\$ 103.23)$ & 0 & 0 \\
N41,000-N80,000 $(\$ 105.81-\$ 206.45)$ & 6 & 2.7 \\
N81,000-N120,000 $(\$ 209.03-\$ 312.26)$ & 8 & 3.6 \\
N121,000-N160,000 $(\$ 312.26-\$ 415.48)$ & 18 & -8 \\
N161,000-N200,000 $(\$ 415.48-\$ 516.13)$ & 193 & 85.8 \\
\hline Total & $\mathbf{2 2 5}$ & $\mathbf{1 0 0}$ \\
\hline
\end{tabular}

Source: Fieldwork (2017)

Utilizing information from Table 6, the mean households' average monthly incomes and the mean households' average monthly incomes for $2^{1} / 2$ years or 30 months were derived as displayed in Table 7 . The result indicates that $193(85.8 \%)$ of the respondents earn a mean average monthly income/and a mean 30 months' average monthly income of N180,500 $(\$ 465.81)$ and $\mathrm{N} 5,415,000(\$ 13,974.19)$ respectively, $18(8 \%)$ earn N140,500 (\$362.58) and $\mathrm{N} 4,215,000(\$ 10,877.42), 8(3.6 \%)$ earn N100,500 (\$259.35) and N3,015,000 $(\$ 7,780.65)$ and $6(2.7 \%)$ earn N60,500 (\$156.13) and N1,815,000 $(\$ 4,683.87)$ respectively.

Table 7: Mean Households' Average Monthly Income/Mean Households' Average Monthly Income for $2^{1 / 2}$ years or 30 months

\begin{tabular}{lccc}
\hline MHAMI & 30XMHAMI & Frequency & Percentage \\
\hline & & & \\
N60500 $(\$ 156.13)$ & N1815000 $(\$ 4,683.87)$ & 6 & 2.7 \\
N100500 $(\$ 259.35)$ & N3015000 $(\$ 7,780.65)$ & 8 & 3.6 \\
N140500 (\$362.58) & N4215000 (\$10,877.42) & 18 & 8.0 \\
N180500 (\$465.81) & N5415000 (\$13,974.19) & 193 & 85.8 \\
Total & & $\mathbf{2 2 5}$ & $\mathbf{1 0 0}$ \\
\hline
\end{tabular}

Source: Fieldwork (2017) 
Result Disclosing the Mean and Standard Deviation of Characteristics that were

Considered in Examining Affordability for Residents of Existing Core Houses in the

\section{Public Core Housing Estates in Anambra State}

Table 8 shows the mean and standard deviation of the characteristics that were considered in examining affordability of core houses in the existing public core housing estates in Anambra State for residents. Mean of households' average monthly income (MHAMI) amounts to 171,255.55 Nigerian Naira (\$441.95) with a standard deviation of 25,632.32. Mean of households' average monthly income for 30 months (30MHAMI) amounts to 5,137,666.66 Nigerian Naira $(\$ 13,258.49)$ with a standard deviation of $768,969.62$. Mean of house price (MHP) within the city (considering the dwelling lot and the prototype) amounts to $8,626,666.66$ Nigerian Naira $(\$ 22,262.36)$ with a standard deviation of $1,640,523.38$. If located outside the city (city border) and the same prototypes considered it amounts to $5,835,333.33$ Nigerian Naira (\$15058.92) with a standard deviation of 1.094.367.88.

Table 8: Result Disclosing the Mean and Standard Deviation of Characteristics that were considered in Examining Affordability for Intended Residents of Existing Core Houses in the Public Core Housing Estates in Anambra State

\begin{tabular}{|c|c|c|c|}
\hline Items & Mean & $\begin{array}{l}\text { Standard } \\
\text { Deviation }\end{array}$ & Decision \\
\hline $\begin{array}{l}\text { Mean of } \\
\text { Households' } \\
\text { Average Monthly } \\
\text { Income in Nigerian } \\
\text { Naira and US } \\
\text { Dollar }\end{array}$ & $\begin{array}{l}\text { N171,255.55 } \\
(\$ 441.95)\end{array}$ & $25,632.32$ & $\begin{array}{l}\text { The mean of the households' average } \\
\text { monthly income falls within 95\%CI } \\
(\mathrm{N} 167888.13-\mathrm{N} 174622.97) \\
(\$ 433.26-\$ 450.64)\end{array}$ \\
\hline $\begin{array}{l}\text { Mean of } \\
\text { Households' } \\
\text { Average Monthly } \\
\text { Income X } 30 \text { months } \\
\left(2^{1} / 2 \text { years }\right) \text { in } \\
\text { Nigerian Naira and } \\
\text { US Dollar }\end{array}$ & $\begin{array}{l}5,137,666.66 \\
(\$ 13,258.49)\end{array}$ & $768,969.62$ & $\begin{array}{l}\text { In } 30 \text { months }\left(2^{1} / 2 \text { years }\right) \text { the mean of } \\
\text { households' average monthly income } \\
\text { is said to be within } 95 \% \mathrm{CI} \\
(\mathrm{N} 5036644.00-\mathrm{N} 5238689.33) \\
(\$ 12,997.79-\$ 13,519.20) \text {. }\end{array}$ \\
\hline $\begin{array}{l}\text { Mean of House Price } \\
\text { Within the City in } \\
\text { Nigerian Naira and } \\
\text { US Dollar }\end{array}$ & $\begin{array}{l}8,626,666.66 \\
(\$ 22,262.37\end{array}$ & $1,640,523.38$ & $\begin{array}{l}\text { The house price within the city } \\
\text { (considering location within the city } \\
\text { and the prototypes they occupied) will } \\
\text { amount to a mean within } 95 \% \text { CI } \\
(8411144.44-8842188.89) \\
(\$ 21,706.18-\$ 22,818.55) \text {. }\end{array}$ \\
\hline $\begin{array}{l}\text { Mean of House Price } \\
\text { outside the city (City } \\
\text { border) in Nigerian } \\
\text { Naira and US Dollar }\end{array}$ & $\begin{array}{l}5,835,333.33 \\
(\$ 15,058.92)\end{array}$ & $1,094,367.88$ & $\begin{array}{l}\text { If location is outside the city and the } \\
\text { prototypes occupied is considered, the } \\
\text { mean house price within } 95 \% \text { CI }\end{array}$ \\
\hline
\end{tabular}




Affordability Within $\quad 0.000 \quad 0.000$
the City

Affordability Within the City - decision

Affordability outside the city (City border)

$0.37 \quad 0.48$
All the prototypes (1,2 and 3

bedrooms) studied within the city are said not to be affordable for any of the respondents

Not Affordable for all

While some of the same prototypes (1 and 2 bedrooms only) studied, if located outside the city are said to be affordable for some of the respondents $(36.9 \%)$

Affordability outside the city (City border) - decision
Affordable for some (36.9\%)

Source: SPSS 22 Descriptive Output

In answering research question 1 on how affordable for intended residents core houses in the existing public core housing estates in Anambra State are, Table 9 shows that all the existing core house prototypes, located within the city (which is the location of all of them at the time they were established - Appendix C) are not affordable for the intended residents. The table further shows that only 83 out of 225 residents $(36.9 \%)$ would be able to afford the prototypes if located outside the city. A majority of 142 out of 225 residents $(63.1 \%)$ would not be able to afford the prototypes even if located outside the city. The results therefore indicate that the prototypes in the existing core housing delivery strategy in Anambra State are not affordable for all the intended residents, located within the city (which is the location of all of them at the time they were established). If located outside the city same prototypes would equally not be affordable for majority (63.1\%).

Table 9: Affordability Test

AFFORDABILITY STATUS

\begin{tabular}{|ll|r|r|r|r|}
\hline & Frequency & Percent & Valid Percent & Cumulative Percent \\
\hline \multirow{4}{*}{ Valid } & Not Affordable & 142 & 63.1 & 63.1 & 63.1 \\
Affordable & 83 & 36.9 & 36.9 & 100.0 \\
& Total & 225 & 100.0 & 100.0 & \\
\hline
\end{tabular}

Source: SPSS 22 Output 
In testing hypothesis 1: affordability for intended residents of core houses in the existing public core housing estates in Anambra State do not significantly vary, Tables 10 and 11 show The Kruskal-Wallis test of variance of affordability for residents of core houses in the existing public core housing estates in Anambra State. The p-value result of $0.000(<0.05)$ implies that affordability for intended residents of core houses in the existing public core housing estates in Anambra State do significantly vary. The null hypothesis was therefore rejected and the alternate hypothesis upheld; which states that affordability for intended residents of core houses in the existing public core housing estates in Anambra State significantly vary.

Table 10: Kruskal-Wallis Test

\begin{tabular}{|l|r|rr|}
\hline \multicolumn{1}{|c|}{ Ranks } \\
\hline
\end{tabular}

Source: SPSS 22 Output

Table 11: Kruskal -Wallis Test

\begin{tabular}{|l|r|}
\hline & \multicolumn{2}{|c|}{ Affordability.Status } \\
\hline Chi-Square & 180.585 \\
Df & 5 \\
Asymp. Sig. & .000 \\
\hline
\end{tabular}

a. Kruskal Wallis Test

b. Grouping Variable: Prototype

Source: SPSS 22 Output 
Objective 2: Relationship between architectural design characteristics affecting design simplicity of public core houses in Anambra State and affordability.

To ascertain the relationship between architectural design characteristics affecting design simplicity of public core houses in Anambra State and affordability, the following variables were investigated. The preference level of the respondents were sought to know if the stated measures will help reduce acquisition cost of initial house. This was done on the background of the technical confirmation obtained from the personal interview protocol of the head of department of Quantity Surveying (Appendix D) that the variables contribute in decreasing house price.

\section{Variable 5: Simplicity in size of initial floor area (SSF):}

This variable sought to know how the design decision on the conservation of size of initial floor area relates to affordability. The respondents showed preference for a 1-bedroom apartment which one can live in and gradually expand to a 3-bedroom apartment, provided this will reduce acquisition cost of initial house. The result in Figure 2 shows that majority of the residents being about $40.4 \%$ and $17.8 \%$ agreed and strongly agreed respectively, followed by about $16.9 \%$ that disagreed and that were neutral respectively, and the rest of $8 \%$ strongly disagreed with the statement.

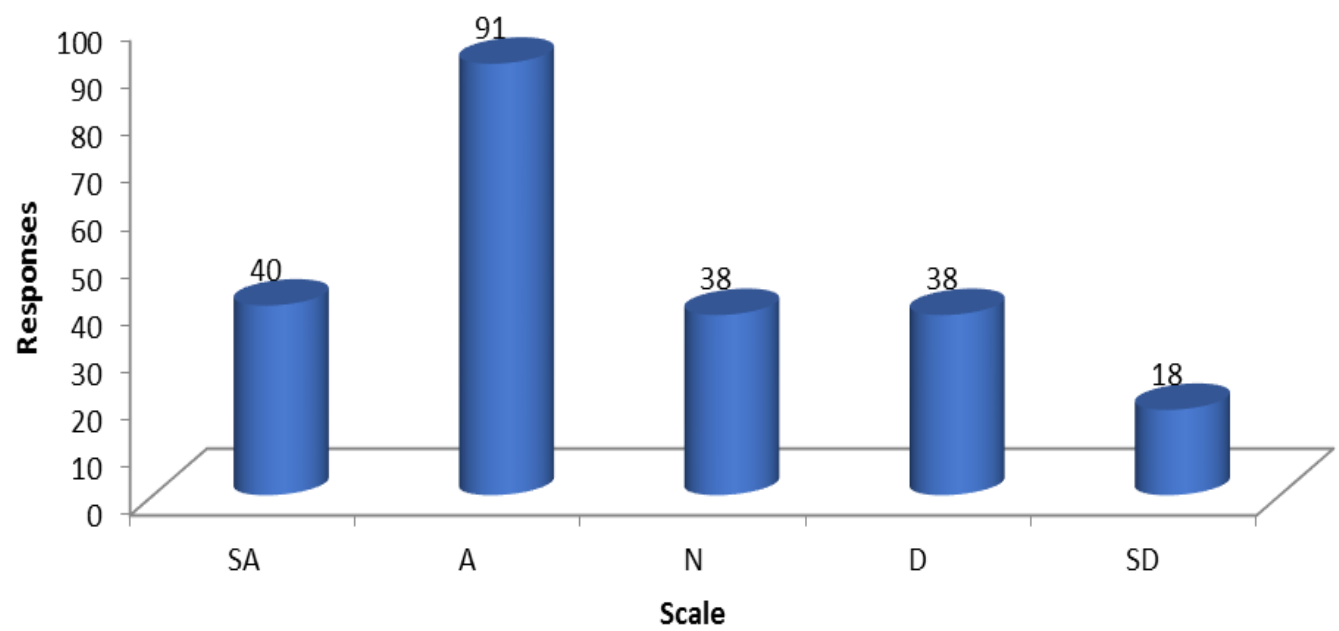

Figure 4: Preference of a 1-bedroom apartment which one can live in and gradually expand to a 3-bedroom apartment, provided this will reduce acquisition cost of initial house. 


\section{Variable 6: Simplicity in geometrical shape of initial floor plan (SGS):}

This variable sought to know how the design decision of the geometrical shape formation adopted for the initial floor plan relates to affordability. The respondents Figure 3 shows that about $43.6 \%$ of the respondents strongly agreed to the statement while $32 \%$ agreed and about $14.2 \%$ were neutral about the statement. Only about $6.7 \%$ disagreed with the statement and the rest of $3.6 \%$ strongly disagreed.

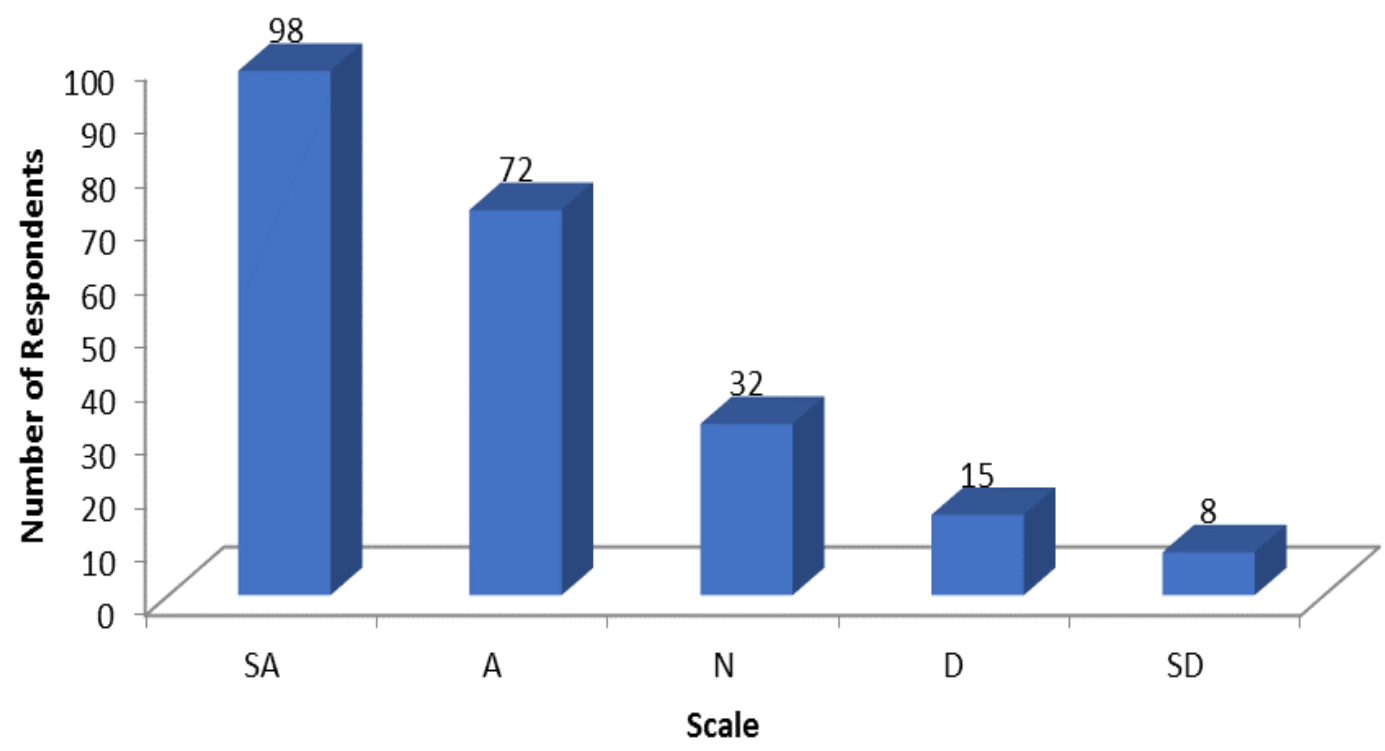

Figure 5: Preference for a square or circular shaped house than a circular one provided this will reduce acquisition cost of initial house.

\section{Variable 5: Simplicity in specification for roof covering (SSR):}

This variable sought to know how the design decision for the type of roofing sheet specified for the house relates to affordability. The respondents indicated preference for a house covered with local building material instead of foreign one, provided that this will reduce acquisition cost of initial house. The result in Figure 4 shows that about $27.1 \%$ of the respondents agreed while $28.4 \%$ strongly agreed, $20 \%$ were neutral while $19.1 \%$ disagreed and the remaining $5.3 \%$ strongly disagreed with the statement. 


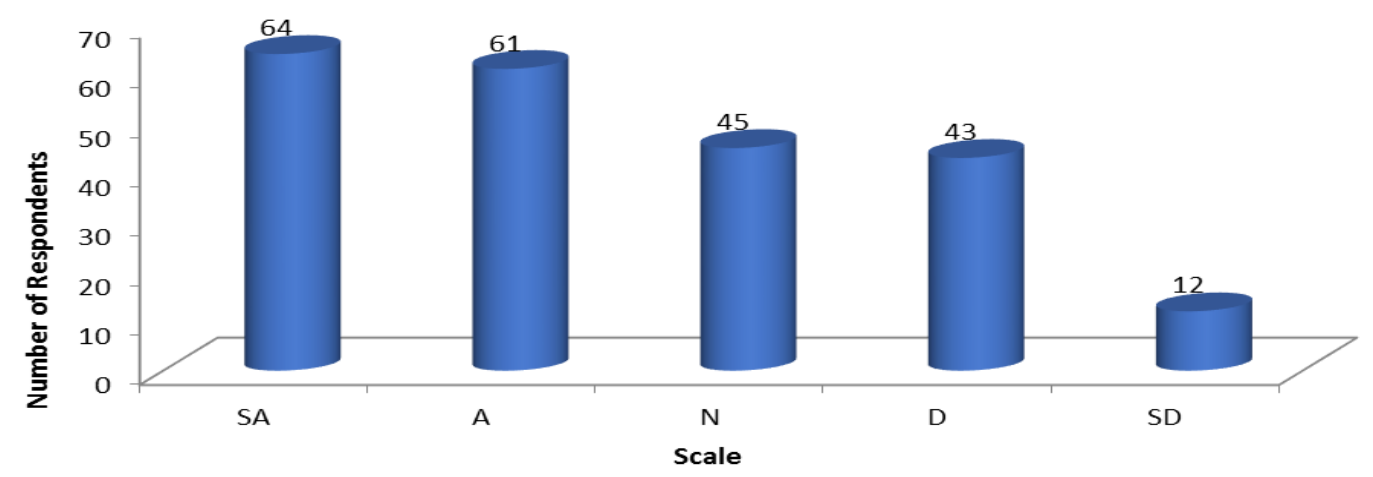

Figure 6: Preference of house covered with local building material instead of foreign one

The summary result on the relationship between architectural design characteristics affecting design simplicity of public core houses in Anambra State and affordability is presented in Table 12, showing a mean and standard deviation of 3.68 and 1.20 respectively.

\section{Table 12: Summary Table for Design Simplicity}

\begin{tabular}{|c|c|c|c|c|c|c|c|c|c|c|}
\hline $\begin{array}{l}\text { Variable } \\
\text { Number }\end{array}$ & $\begin{array}{l}\text { Variable } \\
\text { Desciption }\end{array}$ & $\mathbf{S A}$ & $\mathbf{A}$ & $\mathbf{N}$ & D & SD & $\underset{\mathbf{n}}{\text { Mea }}$ & $\begin{array}{l}\text { Stnd. } \\
\text { Dev. }\end{array}$ & Median & $\begin{array}{c}\text { Skewnes } \\
\text { s }\end{array}$ \\
\hline V3 & $\begin{array}{l}\text { Simplicity in } \\
\text { size of initial } \\
\text { floor area } \\
\text { (SSF) }\end{array}$ & 40 & 91 & 38 & 38 & 18 & 3.43 & 1.19 & 4.00 & -0.534 \\
\hline V4 & $\begin{array}{l}\text { Simplicity in } \\
\text { geometrical } \\
\text { shape of } \\
\text { initial floor } \\
\text { plan (SSP) }\end{array}$ & 98 & 72 & 32 & 15 & 8 & 4.05 & 1.08 & 4.00 & -1.115 \\
\hline \multirow[t]{2}{*}{ V5 } & $\begin{array}{l}\text { Simplicity in } \\
\text { specification } \\
\text { for roof } \\
\text { covering of } \\
\text { initial house } \\
\text { (SSR) }\end{array}$ & 64 & 61 & 45 & 43 & 12 & 3.54 & 1.24 & 4.00 & - 0.377 \\
\hline & $\begin{array}{l}\text { Grand } \\
\text { Mean/Dev. }\end{array}$ & & & & & & 3.68 & 1.20 & & \\
\hline
\end{tabular}

Source: Fieldwork (2017) 
In answering research question 2 on what the relationship is between architectural design characteristics affecting design simplicity of public core houses in Anambra State and affordability, the correlation analysis result between "architectural design characteristics affecting design simplicity" (independent variable) and "affordability" (dependent variable) displayed in Table 13 shows a correlation coefficient of 0.778 . The result indicates that a strong and positive relationship exists between architectural design characteristics affecting design simplicity and affordability.

In testing hypothesis 2: architectural design characteristics affecting design simplicity of public core house in Anambra State has no significant relationship to its affordability, Table 13 shows a p-value of $0.000(<0.05)$. It then implies that architectural design characteristics affecting design simplicity of public core house in Anambra State has a significant relationship to its affordability. The null hypothesis was therefore rejected and the alternate hypothesis upheld, which states that architectural design characteristics affecting design simplicity of public core house in Anambra State has a significant relationship to its affordability.

The results prove that architectural design characteristics affecting design simplicity of public core house in Anambra State, namely: simplicity in size of initial floor area; simplicity in shape of initial floor plan and simplicity in specification for roof covering, has a significant relationship to its affordability, and influences it in a strong and positive.

Table 13: The Correlation Analysis between Architectural Design Characteristics affecting Design Simplicity of Prototype Core House and Affordability Outside the City.

\begin{tabular}{lccccl}
\hline Items & Mean & $\begin{array}{c}\text { Standard } \\
\text { Deviation }\end{array}$ & $\begin{array}{c}\text { Correlation } \\
\text { Coefficient }\end{array}$ & $\begin{array}{c}\text { p- } \\
\text { value }\end{array}$ & Extent of Relationship \\
\hline $\begin{array}{l}\text { Architectural } \\
\text { design } \\
\text { characteristics }\end{array}$ & & & & & \\
$\begin{array}{l}\text { affecting } \\
\text { design }\end{array}$ & & & & & $\begin{array}{l}\text { There is a +ve and strong } \\
\text { relationship existing between } \\
\text { simplicity }\end{array}$ \\
$\begin{array}{l}\text { architectural design } \\
\text { characteristics affecting } \\
\text { design simplicity }\end{array}$ \\
$\begin{array}{l}\text { Affordability } \\
\text { outside the } \\
\text { city }\end{array}$ & 0.68 & 1.20 & 0.778 & 0.000 & \\
\hline
\end{tabular}

Source: Correlation Analysis Output, SPSS 22 


\section{Results}

\section{Objective 1}

All the existing prototypes (1, 2 and 3 bedrooms) studied, in their locations (within the city), were found not affordable for the residents the schemes are intended for. Majority of those that acquired the houses did so through accidental income $(67.6 \%)$ or inheritance $(28.9 \%)$, rather than savings from household income. Only a small percentage of $3.6 \%$ acquired their homes via savings from household income which is the factor used in measuring affordability in this study. The same prototypes (1,2 and 3 bedrooms), if located outside the city (city border) were found still not affordable for all the intended residents, and only the 1 and 2 bedrooms types affordable for the minority (36.9\%) of the intended residents (83 out of 225). Therefore the study found all the existing core house prototypes in their locations (within the city) affordable for none of the intended residents, and affordable only for $36.9 \%$ of them if located outside the city (city border). With a p-value of 0.000 , it was found that affordability for intended residents of core houses in the existing public core housing estates in Anambra State significantly vary. It was discovered from the study that majority of the existing core houses are owned by households of the upper range of the group of intended residents $(94 \%)$ while the lower and middle range owned only $6 \%$. It was also revealed that majority of them $(57.3 \%)$ acquired 3 bedroom prototypes when the houses were first built.

\section{Objective 2}

The study found that architectural design characteristics affecting design simplicity (with a correlation coefficient of 0.778 and p-value of 0.000 between it and affordability) to significantly relate to affordability, influencing it in a strong and positive way. The more the architectural design characteristics affecting design simplicity by reducing size of initial floor area, utilizing simple geometric shapes (squares, rectangles) and specifying simple roof covering (local building material such as clay tile), the more affordable it is.

\section{DISCUSSION}

In the introduction section of this study, two research questions needed to be answered. One relates to the issue of affordability for the intended residents of core houses in the existing public core housing estates in Anambra State, and the other is on the relationship between architectural design characteristics affecting design simplicity of public core houses in Anambra State and affordability. This finding showing that the existing core houses are not affordable for the intended residents confirms the assertions of Napier (2002) and Pandelaki and Shiozaki (2010) that the issue of affordability is one of the challenges faced in the implementation of the core housing concept, despite its potential for affordable housing production. It concurs with the findings of Atamewan and Olagunju (2017) that discovered that the core houses studied were unaffordable for majority $(85.1 \%)$ of the residents in Bayelsa State, Nigeria. The core houses in both contexts were acquired without mortgage financing which could have made the acquisition process stringent. The finding, however, differs with that of Ibem, Aduwo and Ayo-Vaughan (2015) which discovered that the core houses developed in Ogun State, Nigeria public housing were affordable, the core houses constituting $37 \%$ of $92 \%$ of the public houses studied indicated by the respondents to be affordable. It also varies with the finding of Maly and Tamyo (2012) that the core houses 
studied were affordable for majority of the respondents. The disparity is however understandable since the schemes studied in Maly and Tamyo (2012) and Ibem, Aduwo and Ayo-Vanghan (2015) were supported with mortgage provisions contrary to the case in this study where the core houses were acquired through outright purchase and without mortgage support. Moreover, the core houses reviewed were occupied mainly by households of higher rather than lower income dispositions, being apparently not affordable for them. The schemes studied in Ibem, Aduwo and Ayo-Vaughan (2015), were supported by mortgage provisions which provided less financial burdens on residents, the payment being spread over years. The fact that majority (94\%) of the existing core houses in Anambra State are owned by households of the upper range of the group of intended residents while the lower and middle range owned only $6 \%$ shows that the scheme was virtually not beneficial to the lower and middle range.

The finding of this study that a significant relationship (p-value of 0.000 ) which is positive and strong (correlation coefficient of 0.778) exists between architectural design characteristics affecting design simplicity (reducing size of initial floor area; utilizing simple geometric shapes - squares and rectangles, and specifying simple roof covering such - local building material such as clay tile) and affordability relates positively to previous studies. A likely reason for this is that the reduction achieved through design simplicity reduces house price in terms of size, configuration and materials which in turn positively impacts affordability. This result agrees with the connection between the provision of simple shelters for the basic function of protection, identified in Maslow's Hierarchy of Needs theory as the basic need of the housing users (people of lowincomes), and the core housing principle of starting with a simple structure for affordability reasons. The result upholds the affirmation of Ike (1996), Pandelaki and Shiozaki (2010) Gattoni, and Goethert and Chavez (2011) on the role of components of design simplicity, such as use of minimum acceptable standard space adequacy of $7.2 \mathrm{~m}^{2}$ per person, simple geometrical forms, inexpensive building materials, as cost-saving measures in designing for the low-income. It corroborates the findings of Pandelaki and Shiozaki (2010), in the study of core housing in Indonesia, that adjustments made through the reduction of house floor area and lowering of building materials/finishes specification (use of local building materials for example) has helped affordability.

From studies, architectural design characteristics affecting design simplicity has been highlighted to consist of the following: (i) simplicity in size of initial floor area (Abrams, 1964; Ike, 1996; Pandelaki and Shiozaki, 2010; Gattoni, Goethert and Chavez, 2011; Breimer, 2011; VanEenoo, 2011; UMCURA, 2015; Atamewan and Olagunju, 2017); (ii) simplicity in shape of initial house (Bradley, 2011; Esenwein, 2016; Widewalls Editorial ,2017); (iii) simplicity in specification for wall material (Owoeye and Amole, 2012; Olotuah and Taiwo, 2013 and Ayoola and Amole, 2014; Pandelaki and Shiozaki, 2010; Atamewan and Olagunju, 2017) (iv) simplicity in specification for roof covering (Bradley, 2011, Esenwein, 2016) and (v) simplicity in specification for floor covering (Bradley, 2011, Esenwein, 2016).

\section{Implications to Research and Practice}

This study has been able to substantiate that coe housing schemes, though meant to be affordable solutions for public housing provision, are still prone to having affordability challenges, if the architectural design characteristics promoting affordability are neglected. The study was able to establish deficiency in affordability for the intended residents of core 
housing schemes developed at Anambra State. Architectural design simplicity was found to be a contributing factor to the affordility problem. This has added empirical information to the body of knowledge in this area of research. The study has equally provided empirical information to housing design practice on the relevance of architectural design characteristics affecting design simplicity to core housing affotdability.

\section{CONCLUSION}

The background to this study is on the persistent phenomenon of acute housing scarcity being experienced by urban dwellers of developing nations, especially those of them finding it difficult to afford whole houses; and the prevalence of core housing schemes that equally are hardly affordable for them; despite they are the intended beneficiaries. Seemingly this was observed to be true for the study area, Anambra State, Nigeria. Architectural design characteristics affecting design simplicity was observed to be an attribute for improving core housing affordability, yet empirical information on its role has not been established. This relationship will be useful in formulating design strategies for affordable low-cost urban homes. The study first examined affordability for intended residents of the seven prototypes available in the five existing public core housing estates in the study area. It then ascertained the relationship between architectural design characteristics affecting design simplicity of prototype core house and affordability. The study concluded that the existing core houses are not affordable for the residents they are intended for and that affordability for residents significantly varies. It equally concluded the existence of a significant relationship, which is strong and positive between architectural design characteristic in simplicity and affordability.

The result of the findings has shown the important role architectural design characteristics affecting design simplicity plays as an attribute for affordability improvement of core housing schemes. The study therefore recommends that due reflection of this attribute is considered in the conception and implementation of future core housing schemes in the study area in order that they may be benefitial to the low-income urban people, by:

(i) designing to minimize size of initial floor area (studio apartments for households earning below N161, 000 monthly, 1-bedroom and 2-bedroom prototypes for those earning between N161, 000 and N200, 000);

(ii) designing simple geometric plans (such as squares and rectangles); and

(iii) specifying simple roof covering (local building materials such as clay tiles)

\section{Further Studies}

Although the study has shown the effect of architectural design characteristics affecting design simplicity on affordability of core housing, it is limited by focusing only on this aspect. Further studies can explore other aspects of architectural design characteristics crucial for affordability improvement, such as architectural design characteristics affecting flexibility in space - use, adaptability in expansion and dwelling lot value. 


\section{REFERENCES}

Abrams, C. (1964). Man's struggle for shelter in an urbanizing world. Cambridge, M. I. T. Press, 1-2, 174-181.

Aduwo, Edewor, \& Ibem. (2016). Urbanization and housing for low income earners in Nigeria: A review of feautures, challenges and prospects. Mediterranean Journal of Social Sciences, 7(3), 347-357. Retrieved May 2016

Atamewan, E. E., \& Olagunju, R. E. (2017). Incremental construction for sustainable lowincome housing delivery in developing countries: A case study of Bayelsa State, Nigeria. Journal of Sustainable Architecture and Engineering, 20-38.

Bradley, S. (2011). Design Fundamentals.

Breimer, T. (2011). Open building as an approach for more effective core housing implimenation? An exploration. Masters Degree Progrmme in Urban Management and Development, Lund University. Retrieved 2011

Esenwein, F. (2016). Simply American: simplicity in Architectural arrangement, construction and standard. published $\mathrm{Ph}$. D Thesis, University of Pennsylvania, U.S.A.

Faculty of Engineering and Architecture, University of Khartoum, Sudan. (2010). Incremental housing: Its potentials and limitations, evidence from Khartoum, Sudan. Santander, Spain: World Congress on Housing.

Feins, J. D., \& Lane, T. S. (1981). How much for housing? New perspectives on affordability and risk. Abt Books.

Goethert, R. (2010). Incremental housing. a pro-active urban strategy. Incremental Housing Bulletin.

Greene, M., \& Rojas, E. (2008). Incremental construction: A strategy to facilitate access to housing. Environment and Urbanization, 20(1), 19.

Grimmes, O. (1976). Housing for low-income urban families. The John Hopkins University. World Bank Research Publication.

Gudeta, H. A. (2010). An assessment of urban housing supply and affordability in Jimma Town: with reference to condominium housing. M.A Thesis, Institute of regional and local development studies.

Hancock, K. E. (1993). 'Can pay? Won't pay?' or economic principles of affordability. Urban Studies, 30(1), 127-145.

Ibem, E. O., Aduwo, E. B., \& Ayo-Vaughan, E. K. (2015). Assessment of the Sustainability of Public Housing projects in Ogun State, Nigeria: A post-occupancy evaluation approach. Mediterranean Journal of Social Sciences, 6(452), 523-533. Retrieved July 2015.

Ike, E. (1996). Affordable homes: A guide to easy home-building. Lagos: The Show Kemt Ltd.

Ikekpeazu, F. O. (2018). Towards appropriate low-cost housing design for cooperative core housing in Nigeria: Options and prospects. Journal of Resources Development and Management, 41, 37-43.

Irouke, V. M., Ajah, M., \& Ivoke, H. I. (2017). An evaluation of shagari housing programme: case study of three towns - Abakaliki in Ebonyi State, Lokoja in Kogi State and Mbano in Imo State, Nigeria. IIARD, International Journal of Geography and Environmental Management, 3(3), 2504-8821. Retrieved 2017, from www.iiardpub.org

Maly, E., \& Tamyo, K. (2012). An incrementally expandable core house for disaster reconstruction: Two cases in Yogyakarta, Indonesia, After the Central Java Earthquake. Memoirs of Graduate School of Engineering and Systems Informatics, 4, pp. 1-7. 
Maslow, A. H. (1970). Motivation and Personality. New York: Harper and Row

Milligan, V. R. (2003). How different? comparing housing policies and housing affordability consequences for low-income households in Australia and the Netherlands. Utrecht, Sydney: Labor Grafimedia b. v.

Mutisya, K. R. (2015). Housing affordability in Kenya: A case Study of the mortgage housing sector in nairobi. School of Built Environment, University of Nairobi, Kenya, Department of Real Estate and Construction Manangement. Retrieved August 2015

Napier, M. (2002). Core housing, enablement and urban poverty: The consolidation paths of households living in two South Saharan African settlement. ph.D Thesis, University of Newcastle upon Tyne. Retrieved 2012, from http:/www.urbanlandmark.org.za

National Population Commision of Nigeria. (2006). National population census of Nigeria, Federal Republic of Nigeria.

Ndubueze, O. J. (2009). Urban housing affordability and housing policy dilemmans in Nigeria. University of Brbaughan. Centre for Urban and Regional Studies, School of Public Policy.

Olatunde-Aremu, F. T. (2004). Sampling technique:Basic principles of research. Lagos: Concept Publications Limited

Olotuah, A. O., \& Taiwo, A. A. (2013). Housing the urban poor through low-cost housing schemes,. International Journal of Physical and Human Geography, 1(3), 1-8. Retrieved from www.ea-journals.org

Onah, F. O. (2015). Human Resource Management (4th ed.). Enugu: John Jacob's Classic Publishers Ltd.

Pandelaki, E., \& Shiozaki, Y. (2010). The core house concept and its implementation in indonesia, past, present, future. International Journal for Housing Science, 34(44), 233248. Retrieved 11 12, 2017, from www.housingscience.org/html/publications/pdf/34-42.pdf

Sharipah, N., \& Sidi, S. (2011). Quality affordable housing: A theoretical framework for planning and design of quality housing. Journal of Techno-SocialMy JournalMalaysian Citation Centre, 1-10. Retrieved from www.myjournal.my/public/issueviewphp?id $=2787 \&$

Ugonabo, C., \& Emoh, F. (2013). The major challenges to housing development and delivery in Anambra State of Nigeria. Civil and Environmental Research Journal, 3(4).

United Nations Human Settlements Programme, UN-HABITAT. (2009). Structural plans for Awka and Satellite Towns. Retrieved November 16, 2017, from http://www.unhabitat.org

VanEenoo, C. (2011, June 12). Minimalism in art and design: Concepts, influences and perspectives. Journal of Fine and Studio Art, 2(1), 7-12. Retrieved November 16, 2017, from http://www.academicjournals.org

Widewalls Editorial. (2017). Art, history and minimalism.

World Bank. (2018). Nigeria affordable housing project. Documentation/Integrated Safeguards Data Sheet (PID/ISDS). 


\section{APPENDIX A}

\section{INTERVIEW GUIDE:}

Interview with the Head of Town Planning Department, Anambra State Housing Development Corporation, Awka, Anambra State.

Length of Time: 25-30 minutes.

Goal: To obtain knowledge on issues of concern to this research from your point of view based on your experience.

1. Name:

2. Establishment:

3. Department:

4. Designation:

5. What was the establishment date of the following core housing estates?

(i) Semi-detached 3- bedroom bungalow at AHOCOL Phase 1

(ii) Semi-detached 3- bedroom bungalow at AHOCOL Phase 2

(iii) Detached 3-bedroom bungalow at AHOCOL Oganiru Housing Estate, Agu- Awka (AHOCOL 3)

(iv) Detached 2-bedroom bungalow at AHOCOL Inner City Layout, Nkwelle, Awka (AHOCOL 4)

(v) Detached 1-bedroom bungalow at ASHDC Ngozika Housing Estate, Phase 1, Ikwodiaku, Awka

(vi) Detached 2-bedroom bungalow at ASHDC Ngozika Housing Estate, Phase 1, Ikwodiaku, Awka

(vii) Detached 3-bedroom bungalow at ASHDC Ngozika Housing Estate, Phase 1, Ikwodiaku, Awka

6. At the date of establishment of the above estates their locations can be regarded as: within the city or outside the city?

(i)

(ii)

(iii)

(iv)

(vi)

(vii) 


\section{APPENDIX B}

\section{INTERVIEW GUIDE:}

Interview with the Head of Quantity Surveying Department, Anambra State Housing Development Corporation, Awka, Anambra State.

Length of Time: 45-60 minutes.

Goal: To obtain knowledge on issues of concern to this research from your point of view based on your experience.

1. Name:

2. Establishment:

3. Department:

4. Designation:

OBJECTIVE 3 - RELATIONSHIP BETWEEN DESIGN SIMPLICITY OF CORE HOUSE PROTOTYPES IN ANAMBRA STATE AND AFFORDABILITY

5. Reducing the size of the initial floor area of a house strongly contributes to lowering the cost:

(i) Yes

(ii) Neutral

(iii) No

6. Specifying earth block as wall material for house instead of cement block strongly contributes to lowering the cost:

(i) Yes

(ii) Neutral

(iii) No

7. Specifying corrugated asbestos sheets as roof covering for a house instead of longspan aluninum strongly contributes to lowering the cost:

(i) Yes

(ii) Neutral

(iii) No 


\section{APPENDIX C}

\section{INTERVIEW GUIDE:}

Interview with the Head of Estate Management Department, Anambra State Housing Development Corporation, Awka, Anambra State.

Length of Time: 25-30 minutes.

Goal: To obtian knowledge on issues of concern to this research from your point of view, based on your experience.

1. Name:

2. Establishment:

3. Department:

4. Designation:

5. The Anambra State housing provision policy is based on:

(i) Outright purchase of houses

(ii) Sites and services programme

(iii) Mortgage arrangement 


\section{APPENDIX D}

\section{QUESTIONNAIRE}

\section{GENERAL INFORMATION ON THE RESIDENTS}

Please tick $(\sqrt{ })$ in the boxes.

Your name (optional)

1. Estate where you live:

(i) AHOCOL Think Home Estate, Phase 1, Agu-Awka, Awka

(ii) AHOCOL Think Home Estate, Phase 2, Agu-Awka, Awka

(iii) AHOCOL Oganiru Estate, Agu-Awka, Awka

(iv) AHOCOL Inner City Layout, Nkwelle, Awka

(v) ASHDC Ngozika Housing Estate, Phase 1, Ikwodiaku, Awka.

2. The number of years you have lived in the house:
(i) Less than 5 years
(ii) 6-10 years
(iii) $11-15$ years
(iv) $\quad 16-20$ years
(v) over 20 years

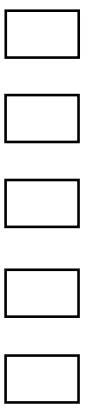

\section{OBJECTIVE 2 - AFFORDABILITY OF CORE HOUSE PROTOTYPES}

3. Household's Average Monthly Income:

(i) $\mathrm{N} 1,000-\mathrm{N} 40,000$

(ii) $\quad \mathrm{N} 41,000-\mathrm{N} 80,000$

(iii) $\quad \mathrm{N} 81,000-\mathrm{N} 120,000$

(iv) $\mathrm{N} 121,000-\mathrm{N} 160,000$

(v) N161,000-N200,000

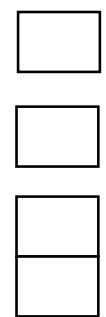


4. Number of bedrooms in your house when first built:
(i) 1 bedroom
(ii) 2 bedrooms
(iii) 3 bedrooms

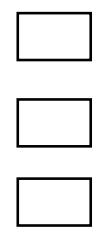

5. Number of bedrooms in your house now:
(i) 1 bedroom
(ii) 2 bedrooms
(iii) 3 bedrooms
(iv) 4 bedrooms
(v) 5 bedrooms
(vi) Greater than 5 bedrooms

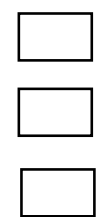

\section{OBJECTIVE 3 - RELATIONSHIP BETWEEN DESIGN SIMPLICITY OF CORE HOUSE PROTOTYPES IN ANAMBRA STATE AND AFFORDABILITY}

\section{(For items 7-12, if it will help reduce acquisition cost of initial house before expansion, you prefer)}

6. 1-bedroom apartment which one can live in and gradually expand to a 3-bedroom apartment:
(i) Strongly disagree
(v) Strongly agree

(ii) Disagree

(iii) Neutral (iv) Agree

7. House that is square or rectangular in shape to one that is circular:

(i) Strongly disagree

(v) Strongly agree

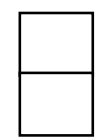

(ii) Disagree

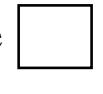
(iii) Neutral

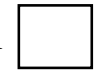
(iv) Agree

8. House roofed with asbestos to one roofed with longspan aluminum:

(i) Strongly disagree

(v) Strongly agree

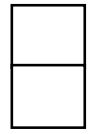

(ii) Disagree

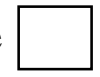

(iii) Neutral

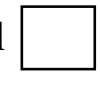
(iv) Agree

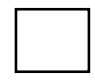

This is the End. Any Personal opinion, comments or advice is appreciated. Thank you. 